\section{Het laatste} woord

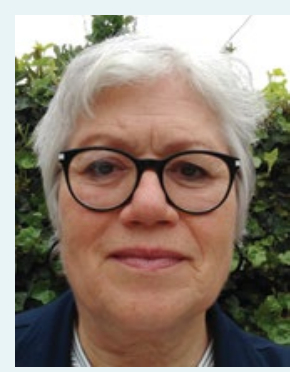

De ergste (eerste golf) van COVID-19 lijkt voorbij. De gevolgen zijn echter zeker nog niet voorbij, zowel voor de zorg als voor de economie. Het resultaat van de maatregelen van de afgelopen tijd wordt geëvalueerd, en stemt niet altijd vrolijk. Tegelijkertijd is er angst voor een tweede golf en lijkt het ergste in Noord- en Zuid-Amerika zelfs nog niet voorbij. Intussen hopen we dat we met een vaccin zelf het laatste woord zullen hebben in de strijd tegen het virus.

In dit nummer kijken wij terug: wat heeft de COVID-19-uitbraak betekend voor de hospices? Wat is er geleerd voor een mogelijk volgende uitbraak? Huisarts Marieke Ausems beschrijft hoe zij in deze tijd anderhalve meter afstand houdend een patiënte begeleidt in de palliatieve fase en euthanasie kan verlenen. Een ander onderwerp in dit nummer is pijnbestrijding bij mensen met een opiaatverslaving. Zowel de kennis en ervaring van verslavingsarts KNMG Hans Post als van verpleegkundig specialisten GGZ Chantal ter Huurne en Karin den Boer worden hier gedeeld.

Voor specialistische palliatieve zorg kunnen zorgverleners in heel Nederland terecht bij de telefonische consultatieteams palliatieve zorg. Het artikel van Mardie Vermunt geeft weer hoe vorig jaar een projectteam van het IKNL bezig was met actualisering en harmonisering van de werkwijze van de verschillende teams, zodat de kwaliteit van de consultatie overal in Nederland gewaarborgd is. Intussen is met het onderbrengen van de consultatieteams naar Fibula weer een stap gezet in de verandering van de organisatie van de palliatieve zorg, na alle andere fusies en reorganisaties van de afgelopen tijd. Voor mij als consulent is het nog geenszins duidelijk waar dit heen gaat en waar 'we' uitkomen.

Wat de redactie betreft, is dit een nummer met onderwerpen waarover niet het laatste woord gezegd is.

Marleen van Venrooij, kaderarts en consulent palliatieve zorg
18 september 2020 - ALS Zorgverleners Congres 2020 (online)

Online congres voor alle professionals die zorg verlenen aan patiënten met ALS, PSMA en PLS. www.als-centrum.nl

\section{1 oktober 2020 - Congres Euthana- sie belicht}

Actualiteiten en besluitvorming voor zorgprofessionals inzake euthanasie.

www.medilex.nl

\section{7-9 oktober 2020 - Online EAPC-congres Palermo}

Het elfde EAPC Research Congress dat in mei in Palermo zou worden gehouden, krijgt vanwege de coronacrisis een online uitvoering. www.eapcresearchcongress2020.eu

8 oktober 2020 - Symposium HOOP: Hulp bij onderwijs over palliatieve zorg

Pasemeco brengt onderwijsprofessionals vanuit de Nederlandse faculteiten bij elkaar, om samen stappen te zetten en het medisch curriculum aan te vullen en te verrijken met palliatieve zorg. Deelnemers ontmoeten vakgenoten, wisselen ervaringen en best practices uit en doen nieuwe ideeën op.

www.pasemeco.nl/symposium

\section{7 oktober 2020 - Werkconferentie}

Zingeving in de buurt: wat kan ik doen?

De verschillende organisaties/mensen die lokaal met zingevingsvraagstukken bezig zijn komen hier met elkaar in contact. Inzicht wordt verkregen in de laatste onderzoeken voor vraagstukken en behoeften rondom zingeving en de mogelijke inzet van vrijwilligers.

www.agora.nl/agenda

18 november 2020 - Congres Palliatieve zorg aan EMB-kinderen

Maatwerk in persoonlijke zorg en begeleiding van kinderen met een ernstige meervoudige beperking en het gezin.

www.medilex.nl

\section{Rob Krol}

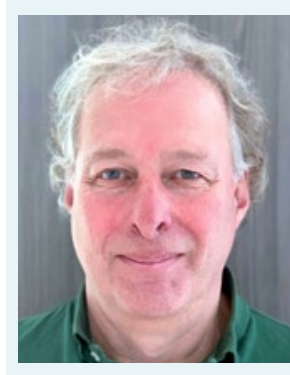

Rob Krol was negen jaar lid van de redactie van Pallium. Ooit was hij oncologieverpleegkundige en nu werkt hij al heel wat jaren als adviseur bij het IKNL. Dit najaar gaat hij met prepensioen, volgend

jaar met echt pensioen.

\section{Hoe kijk je terug op je tijd bij het IKNL?}

"Als een tijd waarin ik in vrijheid dingen van betekenis voor de dagelijkse praktijk heb kunnen opzetten, zoals mijn 'eigen' project Wegwijzer palliatieve zorg voor mensen met een verstandelijke beperking en Zorgconsulenten palliatieve zorg. Mooie samenwerking met netwerkcoördinatoren heb ik ervaren bij de implementatie Zorgpad Stervensfase. De samenwerking met de eerste lijn rond het opzetten van PaTz-groepen en implementatie van de PaTz Portal was ook een dankbaar onderdeel van mijn werk."

\section{Welk voordeel heb je als ex-oncologieverpleeg- kundige?}

"Dat ik de taal van artsen en verpleegkundigen spreek. En mijn kennis kwam van pas bij de redactie van de richtlijnen. Maar het meeste heb ik als adviseur toch gehad aan mijn opleiding VO-Zorginnovatie."

\section{Waarom boeide de palliatieve zorg je zo?} "Op de afdeling Endocrinologie en Nucleaire geneeskunde waar ik tot 2002 werkte, kwamen veel mensen met ongeneeslijke hormoongevoelige tumoren. Dat je als verpleegkundige dan toch nog zo veel kunt betekenen in de palliatieve fase vond ik inspirerend. Verder is de betrokkenheid van mensen die in de palliatieve zorg werken heel erg fijn om te ervaren in de samenwerking. Dat geldt ook voor de Pallium-redactie!”

\section{Wat ga je doen na je pensionering?}

"Even rusten om ruimte te maken voor nieuwe dingen en gewoon te genieten van het leven. Ik ga meer tijd besteden aan natuur en vogels. Niet alleen vogels observeren, maar ik wil ook een bijdrage leveren aan de bescherming ervan." 